\title{
Illness Perception and Quality of Life in Type 2 Diabetes Mellitus Patients in Lampung, Indonesia
}

\author{
Hasanul K. Al-Kayyis ${ }^{1} \&$ Dyah A. Perwitasari ${ }^{1}$ \\ ${ }^{1}$ Faculty of Pharmacy, Ahmad Dahlan University, Yogyakarta, Indonesia \\ Correspondence: Dyah A. Perwitasari, Faculty of Pharmacy, Ahmad Dahlan University, Yogyakarta, Indonesia. \\ Tel: 62-812-2965-376. E-mail: diahperwitasari2003@yahoo.com
}

Received: May 5, 2018 Accepted: June 3, 2018 Online Published: June 11, 2018

doi:10.5539/gjhs.v10n7p136 URL: https://doi.org/10.5539/gjhs.v10n7p136

\begin{abstract}
Aims: The aim of this study was to determine the correlation between illness perception and QoL in Type 2 Diabetes Mellitus (T2DM) patients.

Material and Methods: We used cross-sectional design. The subjects were recruited from the Pringsewu Government Hospital in Lampung, Indonesia, and underwent T2DM treatment from May-July 2016. The subjects have met the inclusion and exclusion criteria. The inclusion criteria were patients age 15-65 with a diagnosis of T2DM with complications for more than 3 months prior and who consented to participate in the study. Participants used the self-reported questionnaire BIPQ (Brief Illness Perception Questionnaire) to measure illness perception and the SF-36 (Short Form-36) questionnaire to measure QoL. Statistical analysis used in this study were Pearson correlation and multivariate linear regression to test between illness perception and quality of life (QoL) domains. The correlation between variable were statistically significant if $p$ value $<0.05$.

Results: The domain of treatment management had the highest score among all BIPQ domains (mean: 8.55; SD: 1.99). Emotional well-being had the highest scores among the SF-36 domains (mean: 72.69; SD: 17.33). The energy domain in QoL was significantly predicted by consequence, personal management, and identity in the BIPQ illness perception components $(\mathrm{p}<0.0001)$. Moreover, the role limitation component was significantly predicted by emotional response, coherence and random blood glucose levels $(\mathrm{p}<0.0001)$.

Conclusions: This study significantly showed weak positive correlations between illness perception and QoL in T2DM patients. An education strategy aimed at changing these negative emotional responses to improve patients' role limitations due to emotional function should be considered.
\end{abstract}

Keywords: Type 2 Diabetes Mellitus, Quality of Life, illness perception, Indonesia

\section{Introduction}

Diabetes is a chronic metabolic disease with symptoms of high blood glucose (Muhil, Sembian, Babitha, Ethiya, \& Muthuselvi, 2014). Based on the Basic Health Research Report, the prevalence of diabetes is approximately $6.9 \%$ in Indonesia, including Type 2 Diabetes mellitus (T2DM) (Anonymous, 2014). The uncontrolled T2DM does not directly cause death but is a risk factor for cardiovascular disease (Inzucchi et al., 2012). T2DM also causes various complications such as retinopathy, peripheral neuropathy, and other sequelae, so that it needs psychological support (Chew, Shariff-Ghazali, \& Fernandez, 2014; Huang, Liu, Moffet, John, \& Karter, 2011). Huang, Brown, Ewigman, Foley, and Meltzer (2007) showed that people with T2DM had a worse quality of life (QoL) compared to normal population. People with T2DM can be prohibited from properly socializing with others due to their stigma for T2DM (Browne, Ventura, Mosely, \& Speight, 2013). A worsening mental health status may promote the development of T2DM complications (Feng \& Astell-Burt, 2017). T2DM complications cause QoL deterioration when compared with patients who do not experience complications (Kiadaliri et al., 2014; Qaseem, Humphrey, Sweet, Starkey, \& Shekelle, 2012). A patient's QoL may be influenced by chronic pain, female gender, lower education level, increased BMI, diabetes-related distress and mobility restriction (Kamradt et al., 2017). Furthermore, illness perception and coping, may influence QoL (Tiemensma, Gaab, Voorhaar, Asijee, \& Kaptein, 2016). Patients may develop their own perspectives about their health, disease and treatment due to the coping process (Dorrian, Dempster, \& Adair, 2009). During the coping process, cognitive and behavioural strategies are required to address the health situation (Van Lankveld, Bosch, Van De Putte, NÄRbng, \& Van Der Staak, 1994). 
Patients with chronic diease, who had severe illness perceptions also had lower QoL scores (Han et al., 2005).

A strong association between poor illness perceptions and depressive symptoms has been previously demonstrated as diabetic patients (Joshi, Dhungana, \& Subba, 2015). Patients' illness perception may also influence treatment adherence (Mohammed, Nagla, Morten, Asma, \& Arja, 2015). A systematic review proposed that by controlling the five dimensions of patients perceptions and targeting treatment, the treatment adherence would improve (Jones, Smith, \& Llewellyn, 2016). Furthermore, robust treatment adherence can increase a patient's QoL (Afshar, Memarian, \& Mohammadi, 2014; Mohammed et al., 2015). Therefore, by modifying the patients' illness perception, the QoL can improve (Jansen et al., 2013). A previous study presented association between illness perceptions and HBA1C test results, and therefore, illness perceptions may influence glycemic control via treatment adherence (Mc Sharry, Moss-Morris, \& Kendrick, 2011). Yadav (2010) showed that negative perceptions can worsen a patient's QoL.

Studies measuring T2DM complications, illness perception and QoL are still limited in Indonesia. A previous study in Indonesia described a positive correlation between treatment adherence and diabetic patient QoL. Some patient characteristics such as sex and age may predict treatment adherence and QoL (D. A. Perwitasari \& Urbayatun, 2016). Moreover, a previous study showed that the type of treatment did not influence the diabetic patient adherence and QoL (Dyah A. Perwitasari, Adikusuma, Rikifani, Supadmi, \& Kaptein, 2014). Therefore, the aim of this study was to determine the correlation between illness perception and QoL in T2DM patients with complications.

\section{Subjects and Methods}

\subsection{Study Subjects}

The subjects of this study were T2DM patients with complications who underwent T2DM treatment at Pringsewu Government Hospital, Lampung, Indonesia, from May to July 2016 and met the inclusion. The inclusion criteria were patients age 15-65 with a diagnosis of T2DM with complications for more than 3 months prior and who consented to participate in the study. The exclusion criteria were pregnancy and a failure to complete the questionnaire. All patients were able to complete the questionnaire by themselves.

\subsection{Data Collection}

Participants used the self-reported questionnaire BIPQ (Brief Illness Perception Questionnaire) to measure illness perception, the SF-36 (Short Form-36) questionnaire to measure QoL. The study was approved by the Ethics Committee of the Ahmad Dahlan University, Yogyakarta, Indonesia (No. 011603060).

\subsection{Instruments}

A demographic data sheet was developed to collect information about the participants. Demographic data included age, sex, social status, education level, occupation, salary, number of complication, treatment, body mass index (BMI), duration of illness and random blood glucose level.

The BIPQ is a self-administered questionnaire with eight domains containing 1-10-point scales. The eight domains are: consequences, timeline, personal management, treatment management, identity, concern, illness coherence and emotional response. For the domains of consequences, timeline, identity, concern and emotional response, the higher the scores, the more negative a patient's perception. In addition, for the rest of domains, the higher scores, the more positive a patient's perception (Broadbent, Petrie, Main, \& Weinman, 2006). We used the Indonesian version of the BIPQ, which was available online at the BIPQ website (Anonymous, 2006).

The SF-36 is a generic QoL questionnaire with 36 questions. The questions are grouped into the following 8 domains: physical function, role limitation due to physical function, role limitation due to emotional problems, energy/vitality, emotional well-being, social function, pain and general health $(0-100$ scale). The higher the domain score, the better the QoL (Anonymous, 1994-2015). This present study used the Indonesian version of the SF-36 which pass through forward-backward procedures and has been met the reliability and validity criteria test (this study has been published previously) (D. A. Perwitasari et al., 2011).

\subsection{Statistical Analysis}

The Pearson correlation coefficient, $r$ values, from the results indicated the strength of the correlations between dependent and independent variables; the higher the $r$ value (nearing +1 or -1 ), the stronger the correlation. Positive values described a linear correlation between variables, and negative values described the opposite. The significance level, $p$ value, represents the correlation between variable were statistically significant if $p$ value $<$ 0.05. Multivariate linear regression analysis was further used to predict the variable from illness perception domains that affect the QoL among T2DM patients with complications. This multivariate analysis was performed 
for adjusting for the clinical characteristics. Clinical characteristics data such as age, random blood glucose level, BMI, and duration of illness were used to find out about clinical characteristics that affect the QoL spesifically.

Table 1. The Sociodemographic and Clinical Characteristics of T2DM patients

\begin{tabular}{|c|c|c|}
\hline Clinical Characteristic $(n=110)$ & \multicolumn{2}{|c|}{ Mean \pm SD } \\
\hline Age (years) & \multicolumn{2}{|c|}{$55.6 \pm 8.4$} \\
\hline Duration of illness (years) & \multicolumn{2}{|c|}{$8.2 \pm 6.7$} \\
\hline Body Mass Index $\left(\mathrm{kg} / \mathrm{m}^{2}\right)$ & \multicolumn{2}{|c|}{$23.8 \pm 3.6$} \\
\hline Random Blood Glucose Levels (mg/dL) & \multicolumn{2}{|c|}{$216.5 \pm 96.3$} \\
\hline Sociodemographic Characteristic $(\mathrm{n}=110)$ & $\mathbf{n}$ & $\%$ \\
\hline \multicolumn{3}{|l|}{ BMI } \\
\hline Underweight $\left(<18.5 \mathrm{~kg} / \mathrm{m}^{2}\right)$ & 8 & 7.27 \\
\hline Normal $\left(18.5-22.9 \mathrm{~kg} / \mathrm{m}^{2}\right)$ & 41 & 37.27 \\
\hline Overweight $\left(23-24.9 \mathrm{~kg} / \mathrm{m}^{2}\right)$ & 21 & 19.09 \\
\hline Obesity $\left(\geq 25 \mathrm{~kg} / \mathrm{m}^{2}\right)$ & 40 & 36.37 \\
\hline \multicolumn{3}{|l|}{ Random Blood Glucose level } \\
\hline Normal $(<200 \mathrm{mg} / \mathrm{dL})$ & 59 & 53.64 \\
\hline Hyperglycaemia ( $\geq 200 \mathrm{mg} / \mathrm{dL})$ & 51 & 46.36 \\
\hline \multicolumn{3}{|l|}{ Sex } \\
\hline Male & 40 & 36.36 \\
\hline Female & 70 & 63.64 \\
\hline \multicolumn{3}{|l|}{ Social Status } \\
\hline Single & 15 & 13.64 \\
\hline Married & 95 & 86.36 \\
\hline \multicolumn{3}{|l|}{ Occupation } \\
\hline Working & 77 & 70.00 \\
\hline Unemployment & 33 & 30.00 \\
\hline \multicolumn{3}{|l|}{ Education *) } \\
\hline Low & 33 & 30.00 \\
\hline Moderate & 43 & 39.09 \\
\hline High & 34 & 30.91 \\
\hline \multicolumn{3}{|l|}{ Salary (USD) } \\
\hline$\leq 177.23$ USD & 63 & 57.27 \\
\hline$>177.23$ USD & 47 & 42.73 \\
\hline \multicolumn{3}{|l|}{ Number of Complications } \\
\hline 1 Complication & 56 & 50.91 \\
\hline$>1$ Complications & 54 & 49.09 \\
\hline \multicolumn{3}{|l|}{ Treatment } \\
\hline Single Oral & 65 & 59.09 \\
\hline Insulin & 36 & 32.73 \\
\hline Combination of Oral and Insulin & 9 & 8.18 \\
\hline
\end{tabular}

Note. ${ }^{*}$ ) Low Education : mean that patient who finished until junior highschool, moderate education : finished until senior high school, and high education : patients who finished bachelor and above. 


\section{Results}

In this study, a total of 110 T2DM patients with complications were recruited during May-July 2016 from the Pringsewu Government Hospital, Lampung. In general, we found an association between illness perception and QoL in T2DM. Table 1 presents the patient characteristics. Most patients were female (63.6\%) and the mean (SD) age was $55.6(8.4)$ years. On average, the patients had experienced T2DM for 8.2 years. Most patients had normal BMIs, and $36 \%(40 / 110)$ were obese. Hyperglycaemia was present in $46.4 \%(51 / 110)$ of patients, according to the random blood glucose test. Approximately 50.91\% (56/110) of patients had more than 1 complication, and most patients used oral mono therapy $(59 \%, 65 / 110)$. The complications included peripheral neuropathy $(40.7 \%$, $37 / 110)$, retinopathy $(22.00 \%, 20 / 110)$, foot ulcer $(3.30 \%, 3 / 110)$ and others $(20.9 \%, 19 / 110)$.

The significant associations were shown by age and emotional well-being $(r: 0.217 ; p: 0.023)$; random blood glucose and role limitation due to physical function $(r:-0.217 ; p: 0.023)$; and random blood glucose and role limitation due to emotional function $(r: 0.264 ; p: 0.005)$. Those associations showed that the older the patient, the better his or her emotional function, and the higher the random blood glucose, the worse the patient's role.

Table 2. Illness perception scores in T2DM patients.

\begin{tabular}{lll}
\hline Domains & Mean & \pm SD \\
\hline Consequence & 5.80 & \pm 2.77 \\
Timeline & 7.07 & \pm 3.15 \\
Personal Management & 7.52 & \pm 2.11 \\
Treatment Management & 8.55 & \pm 1.99 \\
Identity & 5.22 & \pm 2.62 \\
Concern & 4.96 & \pm 3.11 \\
Illness Coherence & 6.74 & \pm 2.46 \\
Emotional Response & 4.30 & \pm 2.68 \\
\hline
\end{tabular}

Note. T2DM: Type 2 diabetes mellitus.

Illness perceptions were reported as descriptive scores from each domain of the perception BIPQ, as shown in Table 2. Descriptive statistics of the BIPQ scores showed that T2DM patients had positive perceptions in all domains. The low scores of consequences, identity, concern and emotional response showed that patients may control their concern and emotional responses. The high scores in the timeline, personal management, treatment management and illness coherence domains showed that Indonesia T2DM patients had positive feelings and perceptions about their disease and treatment. According to patients' beliefs, the main causes of T2DM are unhealthy diet $(92.7 \%, 102 / 110$;), unhealthy lifestyle $(51.8 \%, 57 / 110)$, genetic factors $(40.9 \%, 45 / 110)$, stress $(3.6 \%, 4 / 110)$, obesity $(1.8 \%, 2 / 110)$ and pregnancy $(0.8 \%, 1 / 110)$.

Table 3. QoL scores in diabetes patients.

\begin{tabular}{lcc}
\hline Domains & Mean & \pm SD \\
\hline Physical Function & 69.86 & \pm 26.40 \\
Physical Role due to the physical limitation & 38.86 & \pm 37.95 \\
Emotional Role due to the physical limitation & 41.96 & \pm 40.53 \\
Vitality/Fatigue & 63.00 & \pm 17.24 \\
Emotional Well-being & 72.69 & \pm 17.33 \\
Social Function & 52.25 & \pm 20.61 \\
Pain & 54.84 & \pm 27.77 \\
General Health & 59.64 & \pm \\
\hline
\end{tabular}


Table 4. Correlation Between Demographic Data and Illness Perception (BIPQ) Domains

\begin{tabular}{|c|c|c|c|c|c|c|c|c|c|}
\hline & & CSQ & TL & PM & $\mathrm{TM}$ & ID & $\mathrm{CNC}$ & $\mathrm{CH}$ & $\mathrm{RP}$ \\
\hline \multirow[t]{2}{*}{ Sex } & $r$ & 0.094 & 0.031 & 0.236 & 0.244 & 0.144 & 0.162 & 0.210 & 0.216 \\
\hline & $\mathrm{p}$ & 0.331 & 0.749 & $0.013^{*}$ & $0.010^{*}$ & 0.132 & 0.090 & $0.028^{*}$ & $0.024 *$ \\
\hline \multirow[t]{2}{*}{ Social Status } & $r$ & -0.077 & 0.003 & 0.193 & -0.002 & -0.045 & -0.112 & 0.199 & -0.096 \\
\hline & $\mathrm{p}$ & 0.425 & 0.974 & $0.043^{*}$ & 0.985 & 0.637 & 0.245 & $0.037^{*}$ & 0.316 \\
\hline \multirow[t]{2}{*}{ Education } & $r$ & -0.243 & 0.001 & -0.109 & -0.115 & -0.183 & -0.267 & 0.194 & -0.134 \\
\hline & $\mathrm{p}$ & $0.010^{*}$ & 0.990 & 0.258 & 0.231 & 0.056 & $0.005^{*}$ & $0.042 *$ & 0.161 \\
\hline \multirow[t]{2}{*}{ Occupation } & $r$ & 0.005 & -0.004 & 0.257 & 0.166 & -0.003 & 0.196 & 0.145 & 0.072 \\
\hline & $\mathrm{p}$ & 0.961 & 0.970 & $0.007 *$ & 0.083 & 0.974 & $0.040^{*}$ & 0.130 & 0.456 \\
\hline \multirow[t]{2}{*}{ Salary } & $r$ & -0.203 & 0.056 & -0.137 & -0.062 & -0.207 & -0.234 & 0.119 & -0.105 \\
\hline & $\mathrm{p}$ & $0.033^{*}$ & 0.562 & 0.154 & 0.523 & $0.030^{*}$ & $0.014 *$ & 0.215 & 0.277 \\
\hline \multirow[t]{2}{*}{ Number of Complication } & $r$ & 0.164 & -0.083 & -0.026 & 0.105 & 0.117 & 0.007 & -0.165 & 0.228 \\
\hline & $\mathrm{p}$ & 0.086 & 0.386 & 0.785 & 0.275 & 0.222 & 0.945 & 0.085 & $0.016^{*}$ \\
\hline \multirow[t]{2}{*}{ Treatment } & $r$ & 0.154 & 0.112 & 0.117 & 0.108 & -0.032 & -0.070 & 0.032 & -0.082 \\
\hline & $\mathrm{p}$ & 0.109 & 0.246 & 0.224 & 0.261 & 0.739 & 0.469 & 0.739 & 0.392 \\
\hline
\end{tabular}

Note. ${ }^{*} \mathrm{p}$ value $<0.05$. Abbrevitation : CSQ : Consequece; TL: Timeline; PM : Personal Management; TM : Treatment Management; ID : Identity; CNC : Concern; $\mathrm{CH}$ : Coherence; RP : Representative.

Table 5. Correlation Between Demographic Data and QoL (SF-36) Domains

\begin{tabular}{|c|c|c|c|c|c|c|c|c|c|}
\hline & & PF & PR & ER & $\mathrm{Vt}$ & EW & SF & Pain & GH \\
\hline \multirow[t]{2}{*}{ Sex } & $R$ & -0.129 & -0.069 & -0.064 & -0.006 & -0.125 & -0.053 & -0.238 & 0.175 \\
\hline & $\mathrm{P}$ & 0.178 & 0.474 & 0.503 & 0.953 & 0.192 & 0.583 & $0.012 *$ & 0.067 \\
\hline \multirow[t]{2}{*}{ Social Status } & $R$ & 0.194 & 0.192 & 0.079 & 0.256 & 0.155 & 0.167 & 0.031 & 0.230 \\
\hline & $P$ & $0.043^{*}$ & $0.044 *$ & 0.412 & $0.007^{*}$ & 0.105 & 0.081 & 0.746 & $0.016^{*}$ \\
\hline \multirow[t]{2}{*}{ Education } & $R$ & 0.136 & 0.225 & 0.167 & 0.017 & 0.169 & 0.203 & 0.241 & -0.070 \\
\hline & $\mathrm{P}$ & 0.156 & $0.018^{*}$ & 0.080 & 0.861 & 0.078 & $0.033^{*}$ & $0.011^{*}$ & 0.464 \\
\hline \multirow[t]{2}{*}{ Occupation } & $R$ & 0.092 & -0.047 & 0.011 & -0.062 & -0.172 & -0.234 & -0.236 & 0.141 \\
\hline & $\mathrm{P}$ & 0.338 & 0.627 & 0.911 & 0.519 & 0.073 & $0.014 *$ & $0.013^{*}$ & 0.143 \\
\hline \multirow[t]{2}{*}{ Salary } & $R$ & 0.097 & 0.258 & 0.116 & 0.097 & 0.167 & 0.231 & 0.316 & 0.043 \\
\hline & $\mathrm{P}$ & 0.316 & $0.007^{*}$ & 0.227 & 0.314 & 0.081 & $0.015^{*}$ & $0.001 *$ & 0.652 \\
\hline \multirow{2}{*}{$\begin{array}{l}\text { Number } \\
\text { Complication }\end{array}$} & $R$ & -0.328 & -0.236 & -0.173 & 0.048 & -0.208 & -0.247 & -0.220 & -0.103 \\
\hline & $\mathrm{P}$ & $0.000^{* *}$ & $0.013^{*}$ & 0.071 & 0.621 & $0.029^{*}$ & $0.009^{*}$ & $0.021^{*}$ & 0.286 \\
\hline \multirow[t]{2}{*}{ Treatment } & $R$ & 0.017 & 0.044 & 0.026 & -0.027 & -0.131 & -0.124 & 0.051 & 0.034 \\
\hline & $\mathrm{P}$ & 0.863 & 0.652 & 0.787 & 0.779 & 0.173 & 0.196 & 0.595 & 0.726 \\
\hline
\end{tabular}

Note. *: $\mathrm{p}$ value $<0.05 ; * *$ : $\mathrm{p}$ value $<0.001$. Abbreviation: PF: Physical function; PR: Role Limitation Due To Physical Function; ER: Role Limitation Due To Emotional Problems; Vt: Vitality/Fatigue; EW: Emotional Well-Being; SF: Social Function; GH: General Health. Pearson correlation test.

Table 3 shows the QoL data, which were represented by the mean score for each SF-36 domain. In general, the QoL domain scores were good (more than 50), except for physical role and emotional role due to physical limitation (38.36 and 41.96, respectively). 
The correlation between demographic data and illness perception domains were shown in table 4 . There was a significant weak correlation between demographic data and illness perception domains, except treatment from demographic data $(\mathrm{p}>0.05)$. Sex from demographic data was correlated significantly weak with personal management, treatment management, coherence anda representative $(r: 0.236 ; 0.244 ; 0.210 ; 0.216 ; \mathrm{p}: 0.013 ; 0.01$; 0.028 ; and 0.024 , respectively), and so on.

Table 5 shows the correlation between demographic data and QoL domains, which shown a significant weak correlation between them. Such as, the number of complications was weakly correlated with physical function, role limitation due to physical function, emotinal well-being, social function, and pain $(r:-0.328 ;-0.236 ;-0.208$; $-0.247 ;-0.220 \mathrm{p}:<0.000 ; 0.013 ; 0.029 ; 0.009$; and 0.021 , respectively). The same result from table 4 , treatment that patient received didn't correlated with any of QoL domains $(\mathrm{p}>0.05)$.

Table 6. Correlation between the B-IPQ perception and SF-36 QoL domains.

\begin{tabular}{|c|c|c|c|c|c|c|c|c|c|}
\hline & & PF & PR & ER & $\mathbf{V t}$ & $\mathbf{E W}$ & SF & Pain & GH \\
\hline \multirow{2}{*}{ Consequence } & $\mathrm{r}$ & -0.368 & -0.381 & -0.332 & -0.406 & -0.309 & -0.19 & -0.344 & -0.295 \\
\hline & $\mathrm{p}$ & $<0.001^{* *}$ & $<0.001 * *$ & $<0.001^{* *}$ & $<0.001 * *$ & $0.001 *$ & $0.046^{*}$ & $<0.001^{* *}$ & $0.002 *$ \\
\hline \multirow{2}{*}{ Timeline } & $\mathrm{r}$ & 0.093 & -0.005 & -0.076 & -0.045 & 0.101 & -0.128 & 0.042 & -0.064 \\
\hline & $\mathrm{p}$ & 0.335 & 0.961 & 0.427 & 0.644 & 0.296 & 0.182 & 0.661 & 0.508 \\
\hline \multirow{2}{*}{$\begin{array}{l}\text { Personal } \\
\text { Management }\end{array}$} & $\mathrm{r}$ & 0.149 & 0.013 & 0.111 & 0.195 & 0.16 & 0.102 & 0.06 & 0.294 \\
\hline & $\mathrm{p}$ & 0.119 & 0.896 & 0.249 & $0.041^{*}$ & 0.096 & 0.288 & 0.535 & $0.002 *$ \\
\hline \multirow{2}{*}{$\begin{array}{l}\text { Treatment } \\
\text { Management }\end{array}$} & $\mathrm{r}$ & 0.035 & -0.052 & -0.075 & 0.041 & 0.154 & -0.028 & 0.01 & 0.127 \\
\hline & $\mathrm{p}$ & 0.72 & 0.586 & 0.434 & 0.667 & 0.108 & 0.768 & 0.921 & 0.185 \\
\hline \multirow{2}{*}{ Identity } & $\mathrm{r}$ & -0.252 & -0.315 & -0.254 & -0.431 & -0.304 & -0.018 & -0.322 & -0.236 \\
\hline & $\mathrm{p}$ & $0.008^{*}$ & $0.001^{*}$ & $0.007^{*}$ & $<0.001^{* *}$ & $0.001^{*}$ & 0.849 & $<0.001 * *$ & $0.013^{*}$ \\
\hline \multirow{2}{*}{ Concern } & $\mathrm{r}$ & -0.26 & -0.314 & -0.278 & -0.331 & -0.395 & -0.141 & -0.289 & -0.071 \\
\hline & $\mathrm{p}$ & $0.006^{*}$ & $0.001^{*}$ & $0.003 *$ & $<0.001 * *$ & $<0.001 * *$ & 0.142 & $0.002 *$ & 0.46 \\
\hline \multirow{2}{*}{ Coherence } & $\mathrm{r}$ & 0.336 & 0.243 & 0.257 & 0.167 & 0.139 & 0.018 & 0.209 & 0.212 \\
\hline & $\mathrm{p}$ & $0.000 * *$ & $0.010 *$ & $0.007 *$ & 0.081 & 0.146 & 0.851 & $0.028^{*}$ & $0.026^{*}$ \\
\hline \multirow{2}{*}{ Representative } & $\mathrm{r}$ & -0.264 & -0.302 & -0.333 & -0.322 & -0.334 & -0.194 & -0.269 & -0.213 \\
\hline & $\mathrm{p}$ & $0.005^{*}$ & $0.001 *$ & $<0.001 * *$ & $0.001 *$ & $<0.001 * *$ & $0.043 *$ & $0.004 *$ & $0.025^{*}$ \\
\hline
\end{tabular}

$*$ : $\mathrm{p}$ value $<0.05 ; * *$ p value $<0.001$. Abbreviation: PF: Physical function; PR: Role Limitation Due To Physical Function; ER: Role Limitation Due To Emotional Problems; Vt: Vitality/Fatigue; EW: Emotional Well-Being; SF: Social Function; GH: General Health. Pearson correlation test.

Table 6 shows the Pearson correlation analysis between the BIPQ perception domains and the SF-36 QoL domain. There was a significantly weak correlation between the BIPQ illness perception domains and SF-36 QoL domains $(r:-0.19--0.431 ; \mathrm{p}<0.05)$. These results showed that the majority of patient illness perceptions was weakly correlated with QoL domains. Furthermore, these results would be explain with regression to understand which domains that could predict the QoL. The results can be seen in table 5.

Table 7 shows the multivariate linear regression analysis between BIPQ illness perception domains, clinical characteristic and SF-36 QoL domains. The general results showed that the coefficient of determination $\left(\mathrm{R}^{2}\right)$ was $0.03-0.26$, indicating that $3-26 \%$ variations in QoL were predicted by illness perception domains. Multivariate analysis also demonstrated that emotional response and coherence domains of illness perceptions together with a random blood glucose level may significantly predict the role limitation due to emotional function $\left(\mathrm{R}^{2}: 0.213 ; p\right.$ : $<0.0001$ ). Beside the coefficient of determination, table 5 also showed the predictor of SF-36 QoL domains. For examples, consequence, coherence, and emotional response where the predictor of psyshical function domain. 
Table 7. Multivariate analysis of B-IPQ perception with the SF-36 QoL

\begin{tabular}{|c|c|c|c|c|c|c|c|c|}
\hline \multirow{2}{*}{$\begin{array}{l}\text { Dependent } \\
\text { (SF-36 } \\
\text { Domains) }\end{array}$} & \multirow{2}{*}{$\begin{array}{l}\text { Independent } \\
\text { (Predictor) }\end{array}$} & \multicolumn{2}{|c|}{$\begin{array}{l}\text { Model } \\
\text { Summary }\end{array}$} & \multicolumn{2}{|c|}{ ANOVA } & \multicolumn{2}{|c|}{ Coefficients } & \multirow[b]{2}{*}{$\mathrm{p}$ value } \\
\hline & & $\mathrm{R}$ & $\mathrm{R}^{2}$ & $\mathrm{~F}$ & $\mathrm{p}$ value & $\mathrm{B}$ & Beta $(\beta)$ & \\
\hline \multirow[t]{4}{*}{ Physical Function } & (Constant) & 0.50 & $0.23 *$ & 11.64 & $<0.0001$ & 67.96 & & $<0.0001$ \\
\hline & Consequence & & & & & -2.21 & -0.232 & 0.016 \\
\hline & Coherence & & & & & 3.47 & 0.323 & $<0.0001$ \\
\hline & Emotional Response & & & & & -2.01 & -0.204 & 0.033 \\
\hline \multirow{4}{*}{$\begin{array}{l}\text { Role } r \text { Limitation } \\
\text { Due To Physical } \\
\text { Function }\end{array}$} & (Constant) & 0.47 & $0.20^{*}$ & 9.93 & $<0.0001$ & 48.67 & & $<0.0001$ \\
\hline & Consequence & & & & & -3.45 & -0.252 & 0.011 \\
\hline & Coherence & & & & & 3.53 & 0.229 & 0.011 \\
\hline & Emotional Response & & & & & -3.15 & -0.223 & 0.022 \\
\hline \multirow{4}{*}{$\begin{array}{l}\text { Role Limitation } \\
\text { Due To Emotional } \\
\text { Problems }\end{array}$} & (Constant) & 0.484 & $0.21 *$ & 10.84 & $<0.0001$ & 49.89 & & $<0.0001$ \\
\hline & Coherence & & & & & 4.66 & 0.298 & 0.001 \\
\hline & Emotional Response & & & & & -5.03 & -0.367 & $<0.0001$ \\
\hline & Random Blood Glucose $†$ & & & & & -0.08 & -0.193 & 0.028 \\
\hline \multirow[t]{4}{*}{ Vitality/Fatigue } & (Constant) & 0.53 & $0.26^{*}$ & 13.58 & $<0.0001$ & 67.35 & & $<0.0001$ \\
\hline & Consequence & & & & & -1.51 & -0.243 & 0.021 \\
\hline & Personal Management & & & & & 1.98 & 0.243 & 0.004 \\
\hline & Identity & & & & & -2.01 & -0.306 & 0.004 \\
\hline \multirow{2}{*}{$\begin{array}{l}\text { Emotional } \\
\text { well-being }\end{array}$} & (Constant) & 0.40 & $0.15^{*}$ & 19.95 & $<0.0001$ & 83.60 & & $<0.0001$ \\
\hline & Concern & & & & & -2.20 & -0.395 & $<0.0001$ \\
\hline \multirow[t]{2}{*}{ Social Function } & (Constant) & 0.19 & $0.03 *$ & 4.21 & 0.04 & 58.65 & & $<0.0001$ \\
\hline & Response & & & & & -1.49 & -0.194 & 0.043 \\
\hline \multirow[t]{2}{*}{ Pain } & (Constant) & 0.34 & $0.11 *$ & 14.51 & $<0.0001$ & 74.63 & & $<0.0001$ \\
\hline & Consequence & & & & & -3.45 & -0.344 & $<0.0001$ \\
\hline \multirow[t]{3}{*}{ General Health } & (Constant) & 0.44 & $0.18^{*}$ & 12.55 & $<0.0001$ & 53.45 & & $<0.0001$ \\
\hline & Consequence & & & & & -1.53 & -0.323 & $<0.0001$ \\
\hline & Personal Management & & & & & 2.00 & 0.322 & $<0.0001$ \\
\hline
\end{tabular}

Note. ${ }^{*}: \mathrm{p}<0.0001 ; \uparrow:$ random blood glucose from the clinical characteristic.

Multivariate analysis multiple linear regression

\section{Discussion}

Our study found a correlation between illness perception and QoL in Indonesian T2DM patients. Indonesian T2DM patients had positive perceptions of their illness and treatment. Their QoL was good according to all SF-36 domains. The personal management, consequence and identity of this patient population should be modified to increase vitality. Treatment outcome, emotional response and coherence were also associated with emotional function.

Characteristic disease factors such as hyperglycaemia conditions may influence patient QoL due to disease severity and symptoms. Thommasen and Zhang (2006) showed that high blood glucose levels cause worst SF-36 domains score. On the other hand, older patients have more stable emotional well-being, which could be due to family support. Indonesia has a unique culture in which religion and social relationships can support patient treatment. Indonesian diabetic patients have positive perceptions about their disease and treatment. From the timeline domain, they viewed T2DM as a chronic illness that cannot be cured, but can be controlled with appropriate therapy. Their personal management and illness coherence showed that they were sure they can control 
their illness by themselves and understand their illness and symptoms well. Furthermore, the patients felt that T2DM does not have serious consequences, so they do not worry and do not think too much about the disease. They also did not feel emotionally about T2DM, and they did not report experiencing many symptoms related to T2DM. The same result was reported by Broadbent et al. (2006) about the BIPQ score. Our results of perception measurements are better results compared with Petriček et al. (2009), who showed that the perception measurement obtained worse results in all domain measurements.

We found that the T2DM patients had more energy and fuller of more spirit than expected. Therefore, their daily activities were not limited. The limitations of their physical condition may cause emotional disruptions such as depression and disappointment. This can be due to the coping process of the patients because they have to change lifestyle factors such as food, exercises and daily medication use. For some people, coping is not easy and may influence psychological conditions due to daily activity restriction (Coelho, Amorim, \& Prata, 2003).

The T2DM patients felt that their conditions were the same as other healthy people and did not report feeling more pain than others or hoping that their illness will not get worse. This situation can be caused by social support from family members and/or neighbours, which may influence the diabetes-related distress and patient QoL (Karlsen, Oftedal, \& Bru, 2012). Indonesia's culture is different from that of other countries. Social relationships in Indonesia are very close. People like to visit and to help their neighbours or relatives face their diseases. During visitation, they give both financial and psychological support so that patients feel comfortable and have full spirits to cope with their disease.

Sex from demographic data showed significant weak and positive correlation with personal management, treatment management, coherence, and emotional representative. These results were in line with Boonsatean, Carlsson, Rosner, and Ostman (2018); Tribbick et al. (2017) which showed the correlation between sex and illness perceptions. The education and salary levels have significantly weak and negative correlation with consequence of illness perception domains. The negative correlation shows that the lower the education levels the patient have the higher the consequence to their live. The same meaning applied to salary level. These results were in line with Boonsatean, Rosner, Carlsson, and Östman (2016) study, which shows low education and low income levels had a greater negative effect on their lives. Boonsatean et al. (2016) said that the patients with lower education levels were correlated with low knowledge which affect their self-management strategies and worsen the consequence that they have.

The present study shows a weak and significant correlation between demographic data and QoL. Number of complications were shown to be weakly correlated with physical function, role limitation due to physical function, emotional well-being, social function, and pain domains, meaning that the more the complication, the worse the physical function that patients have, the patients felt shy to meet other people because of their disease, and felt more pain than before they have the complications. Generally, patients with more complications have worsen QoL. The same result was present in Trikkalinou, Papazafiropoulou, and Melidonis (2017) study, which stated that complications has good correlation with QoL, the higher the number of complications the worse the QoL. This study also found that microvascular complications did not have a great effect on QoL, but the combination of microvascular and macrovascular complication had it (Trikkalinou et al., 2017). Patients with more complications felt more pain, which directly affecting the QoL. Majoor et al. (2018) also showed the same result, the pain that the patient received from their illness would affect the QoL.

Generally, we found that patients' illness perception have a significant weak positive correlation with QoL. It shows that the better the patient illness perception, the better the QoL, and the opposite. A previous study had the same results, which showed a significant correlation between illness perception and QoL (Nabolsi, Wardam, \& Al-Halabi, 2013; Scharloo et al., 2007; Tiemensma et al., 2016). As examples, identity has moderate and negative correlation with vitality domain $(r:-0.431 ; \mathrm{p}: 0.001)$. These describe that the higher the patient identity of their symptoms which caused by TD2M, the worst the vitality they have. It caused by the awareness of the patients about their symptoms which lead to their helpless to the illness, and influence to the worst of a patients vitality. According to the correlation between illness perception and QoL, the timeline and treatment management of the BIPQ domains was the only one that did not correlate with the QoL domains. Patients do not think that the duration of their illness is something serious and they also think that it does not affect their QoL. Yaraghchi, Rezaei, Mandegar, and Bagherian (2012) found that patients with negative illness perceptions were more likely to experience future disability, decreased healing time, and increased medical services compared to those with worse illness. The previous study reported that the timeline domain did not correlate with QoL (Timmers et al., 2008).

The QoL were predicted by illness perception domains. Furthermore, in this study we found that $3-26 \%$ variations in QoL were predicted by illness perception domains $\left(\mathrm{R}^{2}: 0.03-0.26 ; \mathrm{p}<0,05\right)$. The results of Van Der Have et al. 
(2013) are in line with these results. The wide variations in the coefficient of determination were caused by different questions in each domain. As examples, the coefficient of determination showed that personal management consequence, and identity explained $26 \%$ of the variance of vitality. Personal management had a significantly weak and positive correlation with vitality $(r: 0.243 ; \mathrm{p}: 0.004)$. Positive value in the result showed that the higher the personal management scores in patients' with diabetes, the best the vitality they had. Consequence and identity had weak and negative correlations with vitality $(r:-0.243 ; \mathrm{p}: 0.021, r:-0.306 ; \mathrm{p}: 0.004$, respectively). Negative values mean that the higher the consequence and identity scores, the worst the vitality the patients had.

Our study found that negative illness perception was correlated with a worse QoL. The previous study had the same results, which showed that diabetic patients' illness perceptions affected their QoL (Mohamed et al., 2016). The present study supported the previous studies regarding the association between illness perception and QoL (Catunda, Seidl, \& Lemétayer, 2017; Rahimi, baljani, \& Zadgasem, 2012; Rawlings, Brown, \& Reuber, 2017). Salemi, Hasemi, and Arefi (2016) also reported that illness perception in BIPQ domains significantly affected the QoL of SF-36 domain scores. Similar results were found in previous studies, which showed that BIPQ perception has a positive correlation with QoL domains (Holbein et al., 2017; Kalantari et al., 2012; Yaraghchi et al., 2012). Jorgensen (2014) showed that cognitive treatment for patients' illness perception increased patients' QoL. Asnani, Barton-Gooden, Grindley, and Knight-Madden (2017) was in line with Jorgensen (2014) which further showed knowledge was strongly correlated with positive illness perceptions.

We show the association among clinical characteristics, illness perception and QoL. The final finding shows that high levels of random blood glucose may cause negative emotional responses. This situation may limit the patient's role which is mostly due to their emotional function. The same result from previous study showed the deterioration of QoL due to the high blood glucose, because patients felt unsatisfied from their treatment (Andayani, Izham, Ibrahim, \& Asdie, 2010). The present study has certain limitations that need to be considered when interpreting the results. Because the sample size of these experiments is relatively small, future studies with larger sample sizes are recommended. Additionally, the data were collected by self-reported instruments, and the probable bias is one of the limitations of the study.

\section{Conclusion}

This study showed the significant weak and positive correlation between illness perception and QoL in T2DM patients. It means that an education strategy is needed to improve patient illness perception, especially regarding emotional response, so that the patient QoL will improve.

\section{Competing Interests Statement}

The authors have no conflict of interest

\section{References}

Afshar, M., Memarian, R., \& Mohammadi, E. (2014). The Effect of Group Discussion on the Quality of Life and HbA1c Levels of Adolescents With Diabetes. Iranian Red Crescent Medical Journal, 16(8), e21110. https://doi.org/10.5812/ircmj.21110

Andayani, T. M., Izham, M., Ibrahim, M., \& Asdie, A. H. (2010). The Association Of Diabetes Related Factor And Quality Of Life In Type 2 Diabetes Mellitus. International Journal of Pharmacy and Pharmaceutical Sciences, 2(1), 139-145. https://doi.org/

Anonymous. (1994-2015). Rand.org. Retrieved August 21 $1^{\text {th }}$, 2015, from https://www.rand.org/health/surveys_tools/mos/36-item-short-form/scoring.html.

Anonymous. (2006). Uib.no. Retrieved November $10^{\text {th }}$, 2014, from http://www.uib.no/ipq/pdf/B-IPQ-Indonesia.pdf.

Anonymous. (2014). labdata.litbang.depkes.go.id. Retrieved November $18^{\text {th }} \quad 2014$, from http://labdata.litbang.depkes.go.id/riset-badan-litbangkes/menu-riskesnas/menu-riskesdas/374-rkd-2013.

Asnani, M. R., Barton-Gooden, A., Grindley, M., \& Knight-Madden, J. (2017). Disease Knowledge, Illness Perceptions, and Quality of Life in Adolescents With Sickle Cell Disease: Is There a Link? Global Pediatric Health, 4, 2333794X17739194. https://doi.org/10.1177/2333794X17739194

Boonsatean, W., Carlsson, A., Rosner, I., \& Ostman, M. (2018). Sex-related illness perception and self-management of a Thai type 2 diabetes population: A cross-sectional descriptive design (Vol. 18).

Boonsatean, W., Rosner, I. D., Carlsson, A., \& Östman, M. (2016). The Influences of Income and Education on the 
Illness Perception and Self-Management of Thai Adults with Type 2 Diabetes. Journal of Diabetes and Metabolic Disorders, 3(2), 100017. https://doi.org/10.24966/DMD-201X/100017

Broadbent, E., Petrie, K. J., Main, J., \& Weinman, J. (2006). The Brief Illness Perception Questionnaire (BIPQ). Journal of Psychosomatic Research, 60, 631-637. https://doi.org/10.1016/j.jpsychores.2005.10.020

Browne, J. L., Ventura, A., Mosely, K., \& Speight, J. (2013). 'I Call It The Blame And Shame Disease': A Qualitative Study About Perceptions Of Social Stigma Surrounding Type 2 Diabetes. British Medical Journal Open, 3(11), e003384. https://doi.org/10.1136/bmjopen-2013-003384.

Catunda, C., Seidl, E. M. F., \& Lemétayer, F. (2017). Illness perception and quality of life of HIV-positive persons: mediation effects of tenacious and flexible goal pursuit. Psychology, Health \& Medicine, 22(2), 129-137. https://doi.org/10.1080/13548506.2016.1146404

Chew, B. H., Shariff-Ghazali, S., \& Fernandez, A. (2014). Psychological aspects of diabetes care: Effecting behavioral change in patients. World Journal of Diabetes, 5(6), 796-808. https://doi.org/10.4239/wjd.v5.i6.796

Coelho, R., Amorim, I., \& Prata, J. (2003). Coping styles and quality of life in patients with non-insulin-dependent diabetes mellitus. Psychosomatics, 44(4), 312-318. https://doi.org/10.1176/appi.psy.44.4.312

Dorrian, A., Dempster, M., \& Adair, P. (2009). Adjustment to inflammatory bowel disease: the relative influence of illness perceptions and coping. Inflammatory Bowel Disseases, 15(1), 47-55. https://doi.org/10.1002/ibd.20583

Feng, X., \& Astell-Burt, T. (2017). Impact of a type 2 diabetes diagnosis on mental health, quality of life, and social contacts: a longitudinal study. British Medical Journal Open Diabetes Research \& Care, 5(1), e000198. https://doi.org/10.1136/bmjdrc-2016-000198

Han, S. W., McColl, E., Barton, J. R., James, P., Steen, I. N., \& Welfare, M. R. (2005). Predictors of quality of life in ulcerative colitis: the importance of symptoms and illness representations. Inflammatory Bowel Disseases, 11(1), 24-34. https://doi.org/10.1097/00054725-200501000-00004

Holbein, C. E., Fogleman, N. D., Hommel, K., Apers, S., Rassart, J., Moons, P., . . Veldtman, G. (2017). A multinational observational investigation of illness perceptions and quality of life among patients with a Fontan circulation. Congenital Heart Disease, 0(0), 1-9. https://doi.org/10.1111/chd.12583

Huang, E. S., Brown, S. E., Ewigman, B. G., Foley, E. C., \& Meltzer, D. O. (2007). Patient perceptions of quality of life with diabetes-related complications and treatments. Diabetes Care, 30(10), 2478-2483. https://doi.org/10.2337/dc07-0499

Huang, E. S., Liu, J. Y., Moffet, H. H., John, P. M., \& Karter, A. J. (2011). Glycemic control, complications, and death in older diabetic patients: the diabetes and aging study. Diabetes Care, 34(6), 1329-1336. https://doi.org/10.2337/dc10-2377

Inzucchi, S. E., Bergenstal, R. M., Buse, J. B., Diamant, M., Ferrannini, E., Nauck, M., . . Matthews, D. R. (2012). Management of hyperglycemia in type 2 diabetes: a patient-centered approach: position statement of the American Diabetes Association (ADA) and the European Association for the Study of Diabetes (EASD). Diabetes Care, 35(6), 1364-1379. https://doi.org/10.2337/dc12-0413

Jansen, D. L., Heijmans, M. J., Rijken, M., Spreeuwenberg, P., Grootendorst, D. C., Dekker, F. W., . . . Groenewegen, P. P. (2013). Illness perceptions and treatment perceptions of patients with chronic kidney disease: different phases, different perceptions? $\mathrm{Br} J$ Health Psychol, 18(2), 244-262. https://doi.org/10.1111/bjhp.12002

Jones, C. J., Smith, H. E., \& Llewellyn, C. D. (2016). A systematic review of the effectiveness of interventions using the Common Sense Self-Regulatory Model to improve adherence behaviours. Journal of Health Psychology, 21(11), 2709-2724. https://doi.org/10.1177/1359105315583372

Jorgensen, B. (2014). Change in Illness Perception to Improve Quality of Life for Chronic Pain Patients. School of Physician Assistant Studies, 477, 1-25.

Joshi, S., Dhungana, R. R., \& Subba, U. K. (2015). Illness Perception and Depressive Symptoms among Persons with Type 2 Diabetes Mellitus: An Analytical Cross-Sectional Study in Clinical Settings in Nepal. Journal of Diabetes Research, 2015, 9. https://doi.org/10.1155/2015/908374

Kalantari, H., Bagherian Sararoodi, R., Afshar, H., Khoramian, N., Forouzandeh, N., Daghagh Zadeh, H., . . . 
Adibi, P. (2012). Relationship between Illness Perceptions and Quality of Life in Patients with Irritable Bowel Syndrome. Journal of Mazandaran University Medicine Science, 22(90), 33-41.

Kamradt, M., Krisam, J., Kiel, M., Qreini, M., Besier, W., Szecsenyi, J., \& Ose, D. (2017). Health-Related Quality of Life in Primary Care: Which Aspects Matter in Multimorbid Patients with Type 2 Diabetes Mellitus in a Community Setting? Public Library of Science One, 12(1), e0170883. https://doi.org/10.1371/journal.pone.0170883

Karlsen, B., Oftedal, B., \& Bru, E. (2012). The relationship between clinical indicators, coping styles, perceived support and diabetes-related distress among adults with type 2 diabetes. $J$ Adv Nurs, 68(2), 391-401. https://doi.org/10.1111/j.1365-2648.2011.05751.x

Kiadaliri, A. A., Gerdtham, U.-G., Eliasson, B., Gudbjörnsdottir, S., Svensson, A.-M., \& Steen Carlsson, K. (2014). Health Utilities of Type 2 Diabetes-Related Complications: A Cross-Sectional Study in Sweden. International Journal of Environmental Research and Public Health, 11(5), 4939-4952. https://doi.org/10.3390/ijerph110504939

Majoor, B. C. J., Andela, C. D., Quispel, C. R., Rotman, M., Dijkstra, P. D. S., Hamdy, N. A. T., . . . Appelman-Dijkstra, N. M. (2018). Illness Perceptions are Associated with Quality of Life in Patients with Fibrous Dysplasia. Calcified Tissue International, 102(1), 23-31. https://doi.org/10.1007/s00223-017-0329-5

Mc Sharry, J., Moss-Morris, R., \& Kendrick, T. (2011). Illness perceptions and glycaemic control in diabetes: a systematic review with meta-analysis. Diabetic Medicine, 28(11), 1300-1310. https://doi.org/10.1111/j.1464-5491.2011.03298.x

Mohamed, R. A. P., Ibrahim, N., Budin, S. B., Omar, A. M., Kamaruddin, N. A., \& Ismail, R. (2016). Inter-Relationship Of Illness Perception, Personality And Quality Of Life Among Type 2 Diabetes Patients : A Cross Sectional Survey. The Social Sciences, 11(3), 234-241. https://doi.org/10.3923/sscience.2016.234.241

Mohammed, S., Nagla, S., Morten, S., Asma, E., \& Arja, A. (2015). Illness perceptions and quality of life among tuberculosis patients in Gezira, Sudan. African Health Sciences, 15(2), 385-393. https://doi.org/10.4314/ahs.v15i2.11

Muhil, M., Sembian, U., Babitha, Ethiya, N., \& Muthuselvi, K. (2014). Study of Auditory, Visual Reaction Time and Glycemic Control (HBA1C) in Chronic Type II Diabetes Mellitus. Journal of Clinical and Diagnostic Research, 8(9), BC11-BC13. https://doi.org/10.7860/JCDR/2014/8906.4865

Nabolsi, M. M., Wardam, L., \& Al-Halabi, J. O. (2013). Quality of life, depression, adherence to treatment and illness perception of patients on haemodialysis. International Journal of Nursing Practice, 1-10. https://doi.org/10.111/ijn.12205

Perwitasari, D. A., Adikusuma, W., Rikifani, S., Supadmi, W., \& Kaptein, A. A. (2014). Quality of Life and Adherence of Diabetic Patients in Different Treatment Regimens. Indonesian Journal of Clinical Pharmacy, 3(4), 107-113 https://doi.org/10.15416/ijcp.2014.3.4.107

Perwitasari, D. A., Atthobari, J., Dwiprahasto, I., Hakimi, M., Gelderblom, H., Putter, H., . . Kaptein, A. A. (2011). Translation and validation of EORTC QLQ-C30 into Indonesian version for cancer patients in Indonesia. Japan Journal of Clinical Oncology, 41(4), 519-529. https://doi.org/10.1093/jjco/hyq243

Perwitasari, D. A., \& Urbayatun, S. (2016). Treatment Adherence and Quality of Life in Diabetes Mellitus Patients in Indonesia. SAGE Open, 6(2), 1-7. https://doi.org/10.1177/2158244016643748

Petriček, G., Vrcić-Keglević, M., Vuletić, G., Cerovečki, V., Ožvačić, Z., \& Murgić, L. (2009). Illness Perception and Cardiovascular Risk Factors in Patients with Type 2 Diabetes: Cross-sectional Questionnaire Study. Croatian Medical Journal, 50(6), 583-593. https://doi.org/10.3325/cmj.2009.50.583

Qaseem, A., Humphrey, L. L., Sweet, D. E., Starkey, M., \& Shekelle, P. (2012). Oral Pharmacologic Treatment of Type 2 Diabetes Mellitus: A Clinical Practice Guideline From the American College of Physicians. Annals of Internal Medicine, 156(3), 218-231. https://doi.org/10.7326/M16-1860

Rahimi, Z., baljani, S., \& Zadgasem, Z. (2012). Investigating the relationship between illness perception and quality of life in hemodialysis patients. iranian journal of critical care nursing, 5(3), 151-158. https://doi.org/

Rawlings, G. H., Brown, I., \& Reuber, M. (2017). Predictors of health-related quality of life in patients with epilepsy and psychogenic nonepileptic seizures. Epilepsy \& Behavior, 68, 153-158. https://doi.org/10.1016/j.yebeh.2016.10.035 
Salemi, S., Hasemi, A. R. G., \& Arefi, M. (2016). The relationship between illness perception, depression and quality of life in patients with psoriasis who referred to Haj Daie dermatology clinic in Kermanshah. Der Pharmacia Lettre, 8(3), 85-89. https://doi.org/

Scharloo, M., Kaptein, A. A., Schlosser, M., Pouwels, H., Bel, E. H., Rabe, K. F., \& Wouters, E. F. (2007). Illness perceptions and quality of life in patients with chronic obstructive pulmonary disease. Journal of Asthma, 44(7), 575-581. https://doi.org/10.1080/02770900701537438

Thommasen, H. V., \& Zhang, W. (2006). Health-related quality of life and type 2 diabetes: A study of people living in the Bella Coola Valley. British Columbia medical journal, 48(6), 272-278. https://doi.org/

Tiemensma, J., Gaab, E., Voorhaar, M., Asijee, G., \& Kaptein, A. A. (2016). Illness perceptions and coping determine quality of life in COPD patients. Int J Chron Obstruct Pulmon Dis, 11, 2001-2007. https://doi.org/10.2147/copd.s109227

Timmers, L., Thong, M., Dekker, F. W., Boeschoten, E. W., Heijmans, M., Rijken, M., . . Kaptein, A. (2008). Illness perceptions in dialysis patients and their association with quality of life. Psychol Health, 23(6), 679-690. https://doi.org/10.1080/14768320701246535

Tribbick, D., Salzberg, M., Connell, W., Macrae, F., Kamm, M., Bates, G., . . Knowles, S. (2017). Differences Across Illness Perceptions in Inflammatory Bowel Disease and Their Relationships to Psychological Distress and Quality of Life. Gastroenterology Nursing, 40(4), 291-299. https://doi.org/10.1097/sga.0000000000000225

Trikkalinou, A., Papazafiropoulou, A. K., \& Melidonis, A. (2017). Type 2 diabetes and quality of life. World Journal of Diabetes, 8(4), 120-129. https://doi.org/10.4239/wjd.v8.i4.120

Van Der Have, M., Minderhoud, I. M., Kaptein, A. A., Leenders, M., Siersema, P. D., Fidder, H. H., \& Oldenburg, B. (2013). Substantial impact of illness perceptions on quality of life in patients with Crohn's disease. Journal of Crohn's and Colitis, 7(8), e292-301. https://doi.org/10.1016/j.crohns.2012.11.002

Van Lankveld, W., Bosch, P. V. T. P. A. D., Van De Putte, L., NÄRbng, G., \& Van Der Staak, C. (1994). Disease-Specific Stressors In Rheumatoid Arthritis: Coping And Well-Being. Br J Rheumatol, 33(11), 1067-1073. https://doi.org/10.1093/rheumatology/33.11.1067

Yadav, S. (2010). Perceived social support, hope, and quality of life of persons living with HIV/AIDS: a case study from Nepal. Quality of Life Research, 19(2), 157-166. https://doi.org/10.1007/s11136-009-9574-z

Yaraghchi, A., Rezaei, O., Mandegar, M. H., \& Bagherian, R. (2012). The Relationship Between Illness Perception and Quality of life in Iranian Patients with Coronary Artery Bypass Graft. Procedia, Social and Behavioral Sciences, 46, 3329-3334. https://doi.org/10.1016/j.sbspro.2012.06.061

\section{Copyrights}

Copyright for this article is retained by the author(s), with first publication rights granted to the journal.

This is an open-access article distributed under the terms and conditions of the Creative Commons Attribution license (http://creativecommons.org/licenses/by/4.0/). 